\title{
İtfaiye Teşkilatında İş Sağlı̆̆ı ve Güvenliği Uygulamalarına Örnek Risk Değerlendirmesi
}

\author{
A Risk Assessment Model for Occupational Health and Safety Practices in the Fire \\ Department
}

\author{
Göksel DEMİR $^{1}(\mathbb{D})$, Semih KUMAŞ ${ }^{2}$ (D) Hacer Handan DEMİR ${ }^{3}$ (D) İbrahim Ertuğrul YALÇIN ${ }^{4}$ \\ ${ }^{l}$ Sağllk Bilimleri Üniversitesi, Hamidiye Sağllk Bilimleri Fakültesi, İs Sağllğı ve Güvenliği Bölümü, \\ 34668, Üsküdar, İstanbul, Türkiye \\ ${ }^{2}$ Akkuyu Nükleer Anonim Şirketi, Gülnar, Mersin, Türkiye \\ ${ }^{3}$ İstanbul Gelişim Üniversitesi, Uygulamall Bilimler Yüksekokulu, Lojistik Bölümü̈, \\ 34310, Avcllar, İstanbul, Türkiye \\ ${ }^{4}$ Bahçeşehir Üniversitesi, Mühendislik ve Doğa Bilimleri Fakültesi, İnşaat Mühendisliği Bölümü, \\ 34353, İstanbul, Türkiye
}

$\ddot{\mathbf{O} z}$

İnsani boyutu yanında ekonomik boyutu da büyük önem taşıyan iş sağlığı ve güvenliği konusunda, Türkiye' de olduğu gibi birçok ülkede yasalar ve yönetmelikler yürürlüğe sokulmuştur. Bu çalışmalar ile çalışanların sağlığını korumaya yönelik ve özellikle işverenler tarafindan uyulması gereken kurallar belirlenmiştir. Özellikle Türkiye'de, 10 Haziran 2003 tarihli Resmi Gazete ile yayınlanan 4857 sayılı iş kanunu kapsamında çeşitli düzenlemeler yapılması ve gerekli tedbirlerin alınması, bu çalışmaların kilometre taşı olarak değerlendirilmektedir. Bu çalışmalar ile içinde bulunduğumuz Avrupa Birliğine uyum sürecinde iş kazaları en aza indirilmiş, böylece devlet yapısı hem ekonomik hem de sosyal açıdan yoğun bir iyileşme sürecine girmiştir. Ancak gerçekleştirilen çalışmalar, İş Sağlığı ve Güvenliği Kanunu'ndaki eksikliklerin giderilmesi gerektiği gerçeğini ortadan kaldıramamıştır. 30 Haziran 2012 tarihiyle Resmi Gazetede yayınlanarak kabul gören ve 01 Ocak 2013 tarihi ile özel işletmelerde uygulamaya koyulan 6331 sayılı İs Sağlığı ve Güvenliği Kanunu gereğince; 01 Temmuz 2014 tarihinden itibaren kamu işletmeleri dahil olmak üzere tüm işletmelerin İş Sağlığı ve Güvenliği tedbirlerini uygulaması ve denetlenmesi zorunlu kılınmıştır. Bu çalışmada; uygulanmaya başlanan 6331 sayılı İş Sağlığı ve Güvenliği Kanununun gereklilikleri, yükümlülükleri ve İstanbul İtfaiye Teşkilatında uygulanması ile ilgili detaylar incelenmiştir.

Anahtar kelimeler: 6331 Sayılı Kanun, İş Sağlığı ve Güvenliği, Risk Değerlendirmesi, İş Kazası.

\begin{abstract}
Occupational health and safety management is an important issue along with its human dimension as well as its economic dimension. In this regard, as in many countries, laws and regulations that aims to protect the employee's health and wellbeing have been entered in force in Turkey. Occupational health and safety rules define both protective and post-accident applications which must be followed by employers. Particularly, taking the necessary precautions by making arrangements with the Labor Law No. 4857 and publication on the Official Gazette of Turkey on 10 June 2003 is considered as the milestone of these studies. With these efforts, occupational accidents were minimized in the duration of adaptation to the European Union, and thus, the state structure has entered a process of intensive recovery both economically and socially. However, the studies have not been able to eliminate the fact that the deficiencies in the Occupational Health and Safety Law should be eliminated. According to the Occupational Health and Safety Law No. 6331, which was published in the Official Gazette on 30 June 2012 and put into use in private companies as of 01 January 2013, and in all companies as of 01 July 2014; enterprises have been required to implement and inspect Occupational Health and Safety rules as required by law. In this study; the requirements, obligations and application of the Occupational Health and Safety Law No. 6331, which has been implemented in the Istanbul Fire Brigade, were examined.
\end{abstract}

Keywords: Law No. 6331, Occupational Health and Safety, Risk asessment, Occupational accident.

\section{GíRiş}

Gelişmiş ülkelerde işverenden personelin başta sağlık olmak üzere güvenliği için koruyucu nitelikte çalışma koşulları sağlanması beklenir. Bu beklenti hem işverenin personeline karşı yerine getirmesi gereken sosyal 
sorumluluğu adına hem de verimliliği arttırma adına gerekmektedir. Ayrıca modern işletmelerde uygulanan Toplam Kalite Yönetimi sisteminin (TKY) uygulanışı maksadıyla çevreye ve insan hayatına duyarlı olan yapının temel taşlarından birisi olan çalışan sağlı̆̆ kavramı üretimin gittikçe beliren ana ayaklarından birisi olarak gün geçtikçe karşımıza çıkmaktadır. İşçi sağlığı ve iş güvenliği (İSiG), "yaşama hakkı" ile doğrudan ilişkili olan, en temel hak ve diğer hakların kullanılmasını sağlayarak ekonomik konularda da önem arz etmektedir. Bu nedenle her dönem konuya yoğun bir ilgi gösterilmekte ve iş kazalarının meslek hastalıkları ile birlikte önlenebilmesi yolunda yoğun çabalar gösterilmektedir. İş Sağllğ 1 ve Güvenliği (ISG) uygulamalarındaki amaç; sağlık ve güvenlik şartlarının iyileştirilmesi için alınacak önlemleri belirlemektedir [1]. Bu kapsamda hedeflenen amaç mesleki risklerin önlenmesi, sağlık ve güvenliğin korunması, risk ve kaza faktörlerine önlemlerin alınması, İSG konusunda işçi ve temsilcilerinin eğitimi, bilgilendirilmesi, görüşlerinin alınması ve dengeli katılımların sağlanması, yürürlükteki mevzuatın doğru bir şekilde uygulanmasıyla İSG ile ilgili her türlü işlemlerin mevzuatlar çerçevesinde yürütülmesini sağlamaktır.

İstanbul İtfaiye Teşkilatı İstanbul Büyükşehir Belediyesine bağlı olarak İtfaiye Daire Başkanlığı adı altında acil durumlara müdahale ve yangın söndürme görevini üstlenen kamu kuruluşudur. Teşkilat görevi gereği operasyonel olarak merkezi çalışma alanları dışında müdahale işlemlerini gerçekleştirmekte ve 24 saat esasına göre vardiya usulü mesai yapılmaktadır. İstanbul İtfaiyesinde operasyonel görevleri yürüten çalışanlarla birlikte olay yeri arkasında Bakım ve Onarım, Personel ve Yazı İşleri, Ambar ve Ayniyat, Halkla İlişkiler, Yangın Önlem ve Denetim, Araştırma, Planlama ve Koordinasyon, Eğitim, Bilgi Teknolojileri, İnşaat ve Emlak gibi destek görevlerini yürüten çalışanlar da yer almaktadır [2]. Araştırmanın amacı, örnek işletmede iş güvenliği uygunluk yapısını saptayarak işletme yönetiminin iş güvenliğ programına ilişkin uygulamalarını, çalışanların ve işletmenin sosyal, coğrafi, fiziki yapısı ile tehlike ve risk yapısını ölçmeye yöneliktir. Böylelikle, iş kazalarının nedenselliği ve çözüm yollarının İSG çerçevesinde incelenmesi mümkün olabilecektir.

İtfaiye Teşkilatı hemen hemen her ülke ve her şehirde 24 saat çalışma ve 48 saat izin hakkı ile görev yapmaktadır. $\mathrm{Bu}$ şekilde bir aylık süreç içerisinde 10 tam gün çalışmaktadır. Her vardiya posta olarak adlandırılmaktadır ve bu postalar A postası, B postası ve C postası olmak üzere ardışık şekilde 3'e ayrılmaktadir.

\section{II. İS SAĞLIĞI GÜVENLİĞi KAVRAMI VE AMACI}

İSG kavramı, uluslararası olarak İSG konusunda söz sahibi olan ILO (Uluslararası Çalışma Örgütü) ve
WHO (Dünya Sağlık Örgütü) ile Türkiye Cumhuriyeti arasında yapılan protokollerle sağlanan anlaşmalar sonucu; 6331 sayılı (ilk defa iş güvenliği ile ilgili müstakil sayılacak bir yasanın) kanunun çıkmasıyla günümüze gelmiştir. Çalışma biçimi ne olursa olsun tüm işçiler, çalışma ortamında mesleki faaliyetlerine bağlı olarak iş kazası ya da meslek hastalığı şeklindeki mesleki risklere maruz kalabilmektedirler. Güvenlik ya da iş güvenliği programının esas amacı, söz konusu riskleri önlemektir [3]. İSG'nin amacının; çalışanları korumak, üretim ile ilgili güvenliği sağlamak ve işletme güvenliği hakkında gerekenleri yapmak olduğu kabul edilir [4].

ISG çok yönlü bir çalışmayı gerektirmektedir. Tasarlama sürecinden başlayarak üretim araçlarının ilk prosesesinden satış sürecinin sonuna kadar Mühendislik Bilimlerinin tüm dalları İSG kapsamındadır. Özellikle koruyucu hekimlik tarafindan bakarsak tıbbın birçok dalı ISG kavramıyla ilişkilidir. İnsan davranışları ile doğrudan etkileşim içindedir. İnsan kaynaklı kazaların, iş kazaları sınıflandırmasında çok büyük bir dilimi yansıtması bu bilgiyi doğrular niteliktedir. Hukuk İSG ile doğrudan beraberdir. Devlet yaptırımı ile alınan ve yürütülen kanunlar, tüzükler, yönetmeliklerle çalışma hayatının düzenlenmesi hukukun temel unsurları sayesinde yerine getirilmektedir. İSG'nin mevzuata uygun olarak uygulanması ancak hukuk kurallarının iyi bilinmesi ve uygulanması ile mümkündür.

\section{1 İş Kazalarının Tanımı ve Nedenleri}

Kaza terimi aniden gelişen, kasıt olmaksızın meydana gelen, beklenmedik olayları ifade eden bir terimdir. Ancak beklenmedik olaylar zarar verici bir olayla sonuçlanmış olsa bile her zaman iş kazası olarak adlandırılmaz [5]. Çalışanın yaralanmasına neden olarak sağlığını bozabilen ya da ölümüne sebep olabilen kaza terimi incelendiğinde, genel anlamiyla "can ya da mal kaybına neden olan kötü olay" biçiminde tanımlandığ 1 görülmektedir [6]. Önceden planı yapılmamış, çoğu zaman kişisel yaralanmalara, araç ve gereçlerde maddi zararlara uğramasına, hatta üretimin bir süre durmasına yol açan bir olaydır [6]. Görüldüğü üzere gerçekleşmesi muhtemel bir olayın iş kazası olarak değerlendirilmesi için mekânsal ve zamansal boyutta kesin bir tutarlılık söz konusu değildir. $\mathrm{Bu}$ boyutta, ancak kanunlar ile sınırlandırılmış zaman ve mekân içerisinde doğru bir sonuca varılabilmektedir. Örneklendirecek olursak çalışanın şahsi aracı ile işyerine gelirken yapmış olduğu bir kaza iş kazası olarak değerlendirilmemektedir. Çünkü kendi iradesi ile işyerine gelmektedir. Buna karşın aynı saatte aynı istikamette işyerinin servis aracı ile yapılan kazalardaki yaralanmalar iş kazası olarak değerlendirilmektedir. Burada işyeri otoritesinin altında olunmasının iş kazasını resmileştirdiğini görmekteyiz. 
Bahsi geçen kaza etmenlerinin ve nedenlerinin sadece kaza olayı meydana geldiğinde değil, Tablo 1 ve 2 den de anlaşılacağı üzere güvenlik tedbirlerinin yeterli şekilde alınmayışından kaynaklanması oldukça düşündürücüdür.

Tablo 1. Alınmayan Önlemlere Göre İş Kazası Nedenleri [3].

\begin{tabular}{|c|c|c|}
\hline & Açıklama & Bulgular \\
\hline 1. & $\begin{array}{l}\text { Güvenlik için bütçe } \\
\text { ayrılmamışsa }\end{array}$ & $\begin{array}{c}\% 43 \text { daha fazla } \\
\text { kaza }\end{array}$ \\
\hline 2. & $\begin{array}{c}\text { Yeni işe alınan işçiler } \\
\text { eğitilmiyorsa }\end{array}$ & $\begin{array}{l}\% 52 \text { daha fazla } \\
\text { kaza }\end{array}$ \\
\hline 3. & $\begin{array}{c}\text { Güvenlik eğitimi için dış } \\
\text { kaynaklar } \\
\text { kullanılmıyorsa } \\
\end{array}$ & $\begin{array}{l}\% 59 \text { daha fazla } \\
\text { kaza }\end{array}$ \\
\hline 4. & $\begin{array}{l}\text { Nezaretçiler için özel bir eğitim } \\
\text { yapılmıyorsa }\end{array}$ & $\begin{array}{l}\% 62 \text { daha fazla } \\
\text { kaza }\end{array}$ \\
\hline 5. & $\begin{array}{c}\text { Güvenlik denetimleri } \\
\text { yapılmıyorsa }\end{array}$ & $\begin{array}{c}\% 40 \text { daha fazla } \\
\text { kaza }\end{array}$ \\
\hline 6. & $\begin{array}{c}\text { Yazılı programları olan } \\
\text { işletmelerle karşılaştırılacak } \\
\text { yazılı bir program } \\
\text { bulunmuyorsa }\end{array}$ & $\begin{array}{l}\% 6 \text { daha fazla } \\
\text { kaza }\end{array}$ \\
\hline 7. & $\begin{array}{c}\text { İşletme kendisin geliştirdiği } \\
\text { değil, hazır program } \\
\text { kullanıyorsa } \\
\end{array}$ & $\begin{array}{c}\% 43 \text { daha fazla } \\
\text { kaza }\end{array}$ \\
\hline 8. & $\begin{array}{c}\text { Yazılı güvenlik program } \\
\text { bulunmuyorsa }\end{array}$ & $\begin{array}{c}\text { \%30 daha fazla } \\
\text { kaza }\end{array}$ \\
\hline 9. & $\begin{array}{c}\text { İşçi güvenlik komiteleri } \\
\text { bulunmuyorsa }\end{array}$ & $\begin{array}{c}\text { \%74 daha fazla } \\
\text { kaza }\end{array}$ \\
\hline 10. & $\begin{array}{l}\text { Uzman güvenlik örgütleriyle } \\
\text { işbirliği yapılmıyorsa }\end{array}$ & $\begin{array}{c}\text { \%64 daha fazla } \\
\text { kaza }\end{array}$ \\
\hline 11. & $\begin{array}{c}\text { Güvenlik başarısını izleyen bir } \\
\text { sistem kurulmamışsa }\end{array}$ & $\begin{array}{l}\% 81 \text { daha fazla } \\
\text { kaza }\end{array}$ \\
\hline 12. & $\begin{array}{c}\text { Kaza raporları belgelenmiyorsa } \\
\text { ya da gözden geçirilmiyorsa } \\
\text { ve/veya gözden geçirenler } \\
\text { güvenliği iş } \\
\text { sorumluluklarının bir parçası } \\
\text { olarak ele almıyorsa. }\end{array}$ & $\begin{array}{l}\% 22 \text { daha fazla } \\
\text { kaza }\end{array}$ \\
\hline 13. & $\begin{array}{l}\text { Nezaretçi, güvenlik konusunda } \\
\text { kendi ücret düzeyini etkileyecek } \\
\text { tarzda hesap vermekle yükümlü } \\
\text { değilse. }\end{array}$ & $\begin{array}{l}\text { \%39 daha fazla } \\
\text { kaza }\end{array}$ \\
\hline 14. & $\begin{array}{c}\text { Üst yönetim güvenlik } \\
\text { farkındalığını } \\
\text { etkin şekilde geliştirmemişse. }\end{array}$ & $\begin{array}{c}\% 47 \text { daha fazla } \\
\text { kaza }\end{array}$ \\
\hline
\end{tabular}

Tablo 2. İş Kazası Nedenleri [7].

\begin{tabular}{ccc}
\hline \multicolumn{3}{c}{ İş Kazalarının Nedenleri } \\
\hline Temel Nedenler & $\begin{array}{c}\text { Dolaylı } \\
\text { Nedenler }\end{array}$ & $\begin{array}{c}\text { Dolaysız } \\
\text { Nendenler }\end{array}$ \\
\hline $\begin{array}{c}\text { Yönetmelikler } \\
\text { Kişisel ve Çevresel } \\
\text { Faktörler }\end{array}$ & $\begin{array}{c}\text { Güvensiz } \\
\text { Uygulamalar } \\
\text { Güvensiz Şartlar }\end{array}$ & $\begin{array}{c}\text { Planlanmamışş̧ } \\
\text { İlemler } \\
\text { Zehirli Gazlar } \\
\text { Tehlikeli Madde }\end{array}$ \\
\hline
\end{tabular}

\section{2 İş Kazalarının Özellikleri}

İş kazasının sık kullanılan açıklaması, Sosyal Sigortalar ve Genel Sağlık Sigortası Kanunu'nda belirtilen açıklamasıdır. Bu açıklamadaki temel unsur, iş kazalarında hangi durumlar için para ödenebileceğinin açıklanmış olmasıdır. İşverenin sorumluluk alanına dışında kalan bazı durumları da kapsayabildiği açıklanmıştır. Ayrıca kaza ile iş kazasını da ayırmak gerekmektedir. Kaza, istenmeyen ve zarar görülen sonuçlara neden olan durumlardır; ama işyerlerinde olması bu olayların kurbanlarının iş kazası geçirdiğinin kanıtı değildir [8].

Kaza sayıları ve işyerlerinde çalışan sigortalı kişi sayıları Tablo 3'de belirtilmiştir. Bu tabloya göre işyerlerindeki çalışan sayısı arttıkça oransal olarak kaza sayılarında bir düşüş söz konusudur. Bu düşüşün içerisinde işletmelerin büyüdükçe ISG normlarını menfi çıkarları ve yasal olarak zorunlulukları gereği uygulamalarının gerçeği yattığı düşünülmektedir.

Tablo 3. SGK 2019 verilerine göre Sigortalı Personel - İşyeri Sayısı ve Kaza Sayısı - İş Kazası Sonucu Ölüm Dağılımları [9].

\begin{tabular}{cccc}
\hline $\begin{array}{c}\text { Sigortalı } \\
\text { Sayısı }\end{array}$ & $\begin{array}{c}\text { İşyeri } \\
\text { Sayısı }\end{array}$ & $\begin{array}{c}\text { Kaza } \\
\text { Sayısı }\end{array}$ & $\begin{array}{c}\text { İş Kazası } \\
\text { Sonucu } \\
\text { Ölüm }\end{array}$ \\
\hline $\mathbf{1 - 3}$ & 1.046 .372 & 5.513 & 110 \\
\hline $\mathbf{4 - 9}$ & 387.890 & 12.226 & 189 \\
\hline $\mathbf{1 0 - 2 0}$ & 133.752 & 17.491 & 230 \\
\hline $\mathbf{2 1 - 4 9}$ & 78.272 & 35.241 & 301 \\
\hline $\mathbf{5 0 - 9 9}$ & 18.753 & 26.947 & 160 \\
\hline $\mathbf{1 0 0 - 1 9 9}$ & 9.033 & 33.337 & 165 \\
\hline $\mathbf{2 0 0 - 2 4 9}$ & 1.726 & 11.235 & 33 \\
\hline $\mathbf{2 5 0 - 4 9 9}$ & 2.913 & 28.451 & 63 \\
\hline $\mathbf{5 0 0 - 1 0 0 0}$ & 951 & 23.471 & 48 \\
\hline$>\mathbf{1 0 0 0}$ & 328 & 27.454 & 327 \\
\hline Toplam & 1.679 .990 & 221.366 & 1.626 \\
\hline
\end{tabular}

\section{III. İŞ SAĞLIĞI GÜVENLİĞİ KAVRAMINDA TARAFLARIN YÜKÜMLÜLÜKLERİ VE GÖREVLERI}

Güvenlik yönetimi bakımından güvenliği işletmeye bir değer olarak kazandırmak, hem yönetimin ve hem de işçilerin bağlılığına dayanmaktadır $[10,11]$. Nitekim bir işletmede iş güvenliği kültürü yaratmada temel unsur nitelikli elemanlardır. İş güvenliği konusunda gerekli hassasiyeti gösteren, tüm hükümlülüklerini yerine getirmek için öncelik veren idari yaklaşım ise kuruma olan bağlılı̆̆ arttırmaktadır. 3.1 İşverenlerin ve Çalışanların Yükümlülükleri ve Görevleri

İşletmenin iş güvenliği performansı üzerinde insan kaynağ1, oldukça büyük bir etkiye sahiptir [3]. İnsan kaynağını menfaatleri gereği değerlendiren işveren, aynı zamanda kişilere, topluma ve devlete karşı bu 
kaynağın korunması konusunda yükümlüdür. Yükümlülük gereği işverenin, işveren vekili tayin ederek İSG çalışmalarını yönetmesi tabidir. Yalnız bu yetki tayini, sorumluluk tayini anlamına gelmemektedir. Olası bir kaza sonrası yükümlülüğün işverende de olduğunun işverence bilinmesi gereklidir.

İşçiler, sertifika programlarının katkısı ile güvenlik eğitiminden geçerek, çalışma ortamında yaşanacak potansiyel zararlar ve tehlikeler hakkında bilgi edinmeli, İSİG bakımından alınacak önlemler ile ilgili faaliyetlere de katılmalıdırlar [3]. İşçiler, çalışma ortamlarında karşılaştıkları sıkıntılar hakkında ilgili kurula bilgi vermelidirler [12].

\section{IV. İTFAIYYE TEŞKILLATINDA ÖRNEK BİR UYGULAMA}

6331 sayılı İş Sağlı̆̆ı ve Güvenliği Kanunu Türkiye'nin iş kazaları ve meslek hastalıkları ile ilgili olan durumunu iyileştirmek, iş sağ lığı ve güvenliğinin bir lüks olmaktan çıkartılarak çalışma yaşamının genel standardı haline getirilmesi amacıyla çıkartılmış ve yasa 30.06.2012 tarihli Resmi Gazetede yayımlanmıştır. Kanunun uygulanmasında kademeli geçiş benimsenmiş̧ir. Bu sebeple itfaiye teşkilatında uygulanacak olan iş sağlı̆̆ güvenliği çalışmaları 01.07.2016 tarihi ile geçerlilik kazanmıştır. Aynı kanunun 2. Maddesinin $\mathrm{b}$ bendinde istisnalar başlı̆̆ 1 altında, Afet ve acil durum birimlerinin müdahale faaliyetleri kısmı kanundan istisna tutulmuştur. Kanun metninden anlaşılacağ istasyonlardan araçların hareket etmesine müteakip olay yerinde veya olay yerine hareket edildiği süre içerisinde gerçekleşebilecek bir kazada 6331 sayllı iş sağlığı güvenliği kanunu uygulanmamaktadır.

\section{RİSK DEĞERLENDIRMESI}

Risk değerlendirmesi: "işyerlerinde var olan tehlikeler ile dışarıdan gelebilecek tehlikelerin, işçilere ya da iş yeri/çevresine verebileceği zararlara karşı alınacak önlemlerin belirlenmesi amacıyla yapılan çalışmalar" olarak ifade edilmektedir. Bu çalışmaların bilimsel olarak metodolojik bir şekilde yapılması, nicel olarak ispatlanabilir belirli bir takım tablo ve şekillerden yararlanılması, değerlendirmenin gerçekçiliğini arttırır. Risk değerlendirmesinin amaçları; risklerin tanımlanması, risk kaynaklarının belirlenmesi, riskin kimleri etkilediği, aciliyeti ve önleme yöntemlerinin belirlenmesidir. Bir kamu işletmesi olan İtfaiye Teşkilatında ilk defa uygulanmaya başlanan risk değerlendirmesi kavramı organizasyon kültürü bağlamında yeni durumlar ortaya çıkmaktadır. Süreç boyunca profesyonel destek alınarak risk değerlendirmesinin uygun şartlar altında yapılması büyük bir zorunluluk teşkil etmektedir. Sadece kanunların öngördüğü şekilde bürokratik olarak risk değerlendirmesini kă̆ıt üzerinde yapmak, olası riskleri tam anlamıyla engelleme açısından yavan kaldığı kadar, sonuç itibari ile ilgilileri tam anlamıyla idari cezalardan kurtarması da söz konusu olmayacaktır.

\subsection{Metodoloji Seçimi ve Tanımlamalar}

Risk değerlendirme çalışmalarının işyerlerinde oldukça büyük oranda kayıpları engellediği ve gerek üretim artı̧̧ı gerekse insan sağlığı konusunda büyük yararlar sağladığı bir gerçektir. Ancak bu çalışmalara sadece kanuni zorunluluk tarafindan bakılarak yapılması ve yanlış uygulamalar gerçekleştirilmesi işyerlerine bir yarar sağlamayacağı gibi, emek ve zaman gibi değerleri tüketecek ve hatta işyerine büyük oranda zarar verecektir. Ayrıca farklı iş kolları ve farklı fiziki şartları bulunan işyeri yapıları olası tehlikelerinde çeşitlenmesine neden olmaktadır. Diğer bir deyişle tüm işyerlerinin tehlike potansiyelleri birbirlerinden farklılıklar göstermektedir. $\mathrm{Bu}$ sebeplerden dolayı tüm işyerlerini kapsayan bir risk analizi metodolojisi bulunmamaktadır. Risk değerlendirme metodolojileri, risk analizi sürecinin matematiksel işlemler ve yorumlarının yapıldığ çekirdek kısmını oluşturmaktadır. Dünyada, günümüzde uygulanan standart halini almış veya almamış birçok risk değerlendirme yöntemi mevcuttur. Risk değerlendirme yöntemlerine baktığımızda "Kalitatif (Nitel) Yaklaşım" ve "Kantitatif (Nicel) Yaklaşım" içeren yöntemlerin bulunduğu görülmektedir. $\mathrm{Bu}$ yöntemlerin hepsi işletmelerdeki çeşitli gereksinimler üzerine geliştirilmiş ve kullanılmaya başlanmıştır [13]. Pek çok faktör, nicel bir risk değerlendirmesine karşı nitel bir karar verme kararını etkileyebilir. Sonuç çıkaracak hiçbir veri mevcut değilse, nicel bir risk değerlendirmesi mümkün olmaz. Veri kalitesi, zaman, personel veya kaynaklardaki kısitlamalar, tam bir kantitatif risk değerlendirmesine izin vermeyebilir. Ancak, veri boşlukları nicel risk değerlendirmesinin önünde bir engel olmak zorunda değildir.

Genel anlamda İtfaiye teşkilatını işletme kavramı, itfaiye istasyonunu da işyeri kavramları ifade etmektedir. İşyeri ek yapıları, yapılacak olan ISG çalışmalarında işyeri ile beraber değerlendirilemeyeceği ve itfaiye istasyonlarında 500 kişinin altında çalışan olduğu düşünüldüğünde her işyeri için bir İSG uzmanının kısmi olarak görevlendirileceği açıktır. $\mathrm{Bu}$ sebepten dolayı metodolojinin basit prosedürlü olacak şekilde, mümkün olduğunca az doküman kullanarak, sebep sonuç ilişkileri içinde gerçekleştirilmesi evrak karmaşasını önleyecektir. Ayrıca işyerinin yapısı ve hizmet sektöründe olması sebebiyle nitel bir çalışma yapılmasının daha uygun olduğu ortaya çıkmaktadır. Bununla beraber, bu işyerlerinde orta düzeyde tecrübeli yöneticilerin de çalışma kapsamına girmesini sağlayacak bir sistem seçilmelidir. 


\subsection{Risk Yönetimi ve Süreci}

Risk yönetimi, çevre güvenliği ve insan hayatı konularında risklerin değerlendirilmesi, iş kazası ve meslek hastalıklarının nedenleri ile bunlara neden olabilecek faktörlerle ilgili en etkin bilgiyi toplayarak sorunların ortaya çıkmasını engellemek için etkili bir güvenlik ağı kurmaktadır [14]. İSG yönetim sisteminin temel amacı işyerlerindeki çalışma olanaklarından kaynaklanan her türlü tehlikeyi ve sağlık riskini azaltarak insan sağlığını etkilemeyen seviyeye düşmesini sağlamaktır [15]. Bu amaç kapsamında "Risk Yönetim Süreci" İSG yönetim sisteminin temel taşını teşkil eder $[13,16]$. Sonuçların değerlendirilmesi için Tablo 4 'teki risk etkisi matrisi oluşturulmuştur. Görülen riskin olabilirlik ve şiddet çarpımı, meydana gelecek olan kazanın şiddeti hakkında bir öngörü edinmeyi sağlar.

Tablo 4. Risk skoru matrisi.

\begin{tabular}{|c|c|c|c|c|c|}
\hline \multirow[b]{2}{*}{$\begin{array}{c}\text { Şiddet } \\
\text { Olabilirlik }\end{array}$} & & & & & \\
\hline & 1 & 2 & 3 & 4 & 5 \\
\hline 1 & $\begin{array}{c}\text { Çok Az Risk } \\
1\end{array}$ & $\begin{array}{l}\text { Az Riskli } \\
2\end{array}$ & $\begin{array}{c}\text { Az Riskli } \\
3\end{array}$ & $\begin{array}{c}\text { Az Riskli } \\
4\end{array}$ & $\begin{array}{l}\text { Az Riskli } \\
5\end{array}$ \\
\hline 2 & $\begin{array}{c}\text { Az Riskli } \\
2\end{array}$ & $\begin{array}{c}\text { Az Riskli } \\
\quad 4\end{array}$ & $\begin{array}{c}\text { Az Riskli } \\
6\end{array}$ & $\begin{array}{c}\text { Riskli } \\
8\end{array}$ & $\begin{array}{c}\text { Riskli } \\
10\end{array}$ \\
\hline 3 & $\begin{array}{c}\text { Az Riskli } \\
3\end{array}$ & $\begin{array}{l}\text { Az Riskli } \\
\quad 6\end{array}$ & $\begin{array}{c}\text { Riskli } \\
9\end{array}$ & $\begin{array}{c}\text { Riskli } \\
12\end{array}$ & $\begin{array}{c}\text { Riskli } \\
15\end{array}$ \\
\hline 4 & $\begin{array}{c}\text { Az Riskli } \\
4\end{array}$ & $\begin{array}{c}\text { Riskli } \\
8\end{array}$ & $\begin{array}{c}\text { Riskli } \\
12\end{array}$ & $\begin{array}{c}\text { Çok Riskli } \\
16\end{array}$ & $\begin{array}{c}\text { Çok Riskli } \\
20\end{array}$ \\
\hline 5 & $\begin{array}{l}\text { Az Riskli } \\
5\end{array}$ & $\begin{array}{c}\text { Riskli } \\
10\end{array}$ & $\begin{array}{c}\text { Riskli } \\
15\end{array}$ & $\begin{array}{c}\text { Çok Riskli } \\
20\end{array}$ & $\begin{array}{c}\text { Çok Yüksek Riskli } \\
25\end{array}$ \\
\hline
\end{tabular}

Muhtemel bir olay sonrası beklenen zararın derecelendirilmesi için Tablo 5' teki risk etki derecesi

kullanılarak etki puanına göre risk skoru hesaplaması yapılmalıdır.

Tablo 5. Risk etkisi.

\begin{tabular}{c|cc} 
Etki & Etki Derecesi & Puan \\
\hline $\begin{array}{c}\text { Düşük oranda hafif çizikler, burkulmalar } \\
\text { Hafif yanık, Hafif yaralanma, kayma, takılma ve benzeri } \\
\text { nedenleri düşme }\end{array}$ & Çok Hafif & 1 \\
$\begin{array}{c}\text { Sıkışma, ezilme kulak zarı hasarı, üzerine cisim düşmesi } \\
\text { ve çarpması, yüksekten düşme }\end{array}$ & Hafif & 2 \\
$\begin{array}{c}\text { Boğulma, zehirlenme, ciddi yaralanma, uzuv kopması, } \\
\text { kafatası yaralanmaları, sürekli iş, göremezlik, } \\
\text { Ölü sayısının çok olması (birden fazla ölüm), }\end{array}$ & Orta & 3 \\
\end{tabular}

Muhtemel bir olay sonrası beklenen zararın derecelendirilmesi için Tablo 6' da bulunan risk olasılığ kullanılarak etki puanına göre risk skoru hesaplaması yapılmalıdır.

Tablo 6. Risk olasılı̆̆ı.

\begin{tabular}{c|cc} 
Ortaya Çıkma Olasılığı & Olasilık Derecesi & Puan \\
\hline Nadiren & Çok Küçük & 1 \\
Çok az (yılda bir kez) & Küçük & 2 \\
Az (yılda birkaç kez) & Orta & 3 \\
Sıklıkla (ayda bir) & Yüksek & 4 \\
Çok sıklıkla (haftada bir) & Çok Yüksek & 5
\end{tabular}

\section{SONUÇ VE ÖNERILLER}

Yapılan çalışma ilgili kanunlar ve kanunlara bağlı olarak yayınlanan yönetmelik ve mevzuatlar doğrultusunda, işyerindeki risk faktörleri değerlendirilerek yapılmıştır. Her iş yerindeki tehlike unsurlarının yapıları farklı olduğu kadar çözüm metotları da farklılık arz etmektedir. Bu sebepten dolayı özellikle risk analizi esnasındaki bu çalışma iş kolunun tamamen ilgili olmadığı bir ișyerine örnek teşkil etmemektedir. Diğer bir deyişle bu çalışma örnekten ziyade bir kılavuz niteliği taşımaktadır. İSG konusunda benzer bir çalışmanın yapılabilmesi için tüm risk etmenlerinin, yapılan işin gereği farklı bir çalışma tarzı ve metot ile yapılarak değerlendirilmesi daha isabetli ve kararlı sonuçlar verecektir.

İstasyon içi uygulamalarda "nace kodu" olarak adlandırılan kod ile itfaiye istasyonunun taşıdığı risk potansiyeli dikkate alındığında, itfaiye istasyonları belirlenen cetvele göre çok tehlikeli risk kapsamında yer almaktadır. $\mathrm{Bu}$ sebepten dolayı Risk değerlendirmelerinin en geç 2 yılda 1 yapılması gerekmekte aynı zamanda iş sağlığı güvenliği kurul toplantılarının da her ay yapılması gerekmektedir. Kurul kararları noter veya ilgili müdürlükten imzalanan onaylı deftere kaydedilmektedir. Kurul kararları itfaiye istasyonlarının dahilinde olası risklerin minimuma indirilmesi ile ilgili kararları kapsar ve kararlar iş güvenliği uzmanı ile iş yeri hekimi tarafindan işveren veya işveren vekiline tebliğ 
edilir. Gerekli düzenlemeler en kısa zamanda yapılarak bir sonraki kurul toplantısında önceki kurulda yer alan tebliğlerin hangi oranda gerçekleştirildikleri gündeme alınarak ilerleme sağlanır. Kanun içeriği ile; Kurul dahilinde bulunan seçimle gelmiş veya görevlendirilmiş kişiler işyerinde hiçbir şekilde kötü davranış ve muameleye maruz kalamaz veya özlük haklarından alıkonulamazlar.

İşyerlerindeki güvenli ve sağlıklı çalışma standartlarına kavuşulması, güvenlik ikliminin benimsenerek uygulanması yanında; yönetmelikte belirtilen görev, yetki ve sorumluk zinciri içerisinde çalışan, işveren, devlet, STK'lar etkin ve entegre şekilde birlikte çalışmalıdır. Alınacak önlemleri kısa zamanda yerine getirmek üzere ciddi, somut adımlar atılması evrensel bir değer olan insan yaşamının korunması yanında işyerlerinin varoluş amacı olan üretim güvenliğini de koruyacaktır. Sonuç olarak; bu çalışmada itfaiye teşkilatında bir risk değerlendirmesi, kılavuz önerisinde bulunulmuş ve değerlendirilmiştir.

\section{KAYNAKLAR}

[1] Lucas D.L., Laurel D.K., Viktor E.B., \& Jennifer M.L. (2014). Application of a translational research model to assess the progress of occupational safety research in the international commercial fishing industry, Safety Science, 64, 71-81.

[2] İBB - İstanbul Büyükşehir Belediyesi (2019). www.ibb.gov.tr.

[3] Demirbilek, T. (2005). İş güvenliği kültürü. İzmir: Legal Yayınları.

[4] Aydın, M. (2012). 2200 Soruda iş sağlığı ve güvenliği. Ankara: Riskmed Yayınları.

[5] Güven, E. (1970). İş kazası yönünden sosyal politika sorunları. Eskişehir Anadolu Üniversitesi Yayınları.

[6] Güzel, A., \& Okur, C. (2003). Sosyal güvenlik hukuku, 9. Baskı. İstanbul: Beta Yayınları.
[7] Yanturalı, B. (2015). İş sağlığı ve güvenliğinde risk değerlendirmesi ve bir uygulama çalışması (Master's thesis, Balıkesir Üniversitesi Fen Bilimleri Enstitüsü).

[8] Özveri, M. (2018). Türkiye'de Meslek Hastalıkları Alanında Yaşanan Hukuki Açmazlar. Calisma ve Toplum, 57(2).

[9] SGK - Sosyal Güvenlik Kurulu (2019). http://www.isteguvenlik.tc.

[10] Hovden, J., Lie, T., Karlsen, J.E., Alteren, B. (2008). The safety representative under pressure. A study of occupational health and safety management in the Norwegian oil and gas industry, Safety Science, 46(3), 493-509.

[11] Dudu, H. (2019). İş Sağliği ve Güvenliği Kültürünün İş Tatmini ve İş Kazalarina Etkisi (Doctoral Dissertation, İstanbul Aydin Üniversitesi Fen Bilimleri Enstitüsü).

[12] Geldi, M. (2017). Ülkemizde sağlık kurumlarında iş sağlığı ve güvenliği/Occupational health and safety in Turkey health care institutions. (Master's thesis, Hacettepe Üniversitesi, Fen Bilimleri Enstitüsü).

[13] Özkılıç, Ö. (2007). İş sağlığı güvenliği ve çevresel etki risk değerlendirmesi. İstanbul: Mess Yayınları.

[14] Özkılıç, Ö. (2005). İş sağlığı ve güvenliği yönetim sistemleri ve risk değerlendirme metodolojileri. 3.Baskı. İstanbul: Tisk Yayınları.

[15] Lau, W.K.Y., Liang, P., Man, Y.B., Chung, S.S., Wong, M.H. (2014). Human health risk assessment based on trace metals in suspended air particulates, surface dust, and floor dust from e-waste recycling workshops in Hong Kong, China, Environmental Science and Pollution Research, 21(5), 3813-3825.

[16] Koçak, D. (2019). Bir Kömür Madeninde İş Sağlığı ve Güvenliği Risk Değerlendirmesi İçin Uygun Yöntem Seçimi. (Master's thesis, Hacettepe Üniversitesi, Fen Bilimleri Enstitüsü). 